\title{
Origin and Development of Indian Logic and Buddhist Logic
}

\author{
Ven.Dr. LenagalaSiriniwasa Thero \\ Head, Department of Sanskrit, Buddhist and Pali University of Sri Lanka - Homagama, Sri Lanka
}

\section{The Development of Indian Logic}

It is very difficult to give satisfactory chronological accounts of the rise and growth of Indian Logic for the reason that the texts, which the science of logic or various logical terms have been mentioned or used, have so far failed to be dated with certainly. The earliest reference to logic or science of debate seem to be contained in chāndogyaupanisad where Nārada includes among the disciplines studied by him, one called vākovakyam(Ch.U.7.1.2). The term is explained by Sankarācārya as meaning logic(tarkasāstra),but it seems to signify the art or science of debate. Among later works the arthasāstra of Kautilya (400 B.C.) mentions logic under the name of anvikssiki, which is the first among the four disciplines, alluded to by him (arthsāstra 1-2.p.6). Perhaps even in those days, as now, the followers of reason or logic were not very orthodox people. Arthasāstra says that a person well versed in the art of governing ought to know logic also. Next important references are to be met with in the kathāvatthu (300 B.C.), which is a part of the abhidharmapi $\mu a k a$ in Buddhism. The work mentions Anuyoga(inquiry),âharana(illustration), patina (proposition) [1]. In the Mahābhäratanot only the term Upanayana (application of reason), Niggaha(Nigraha-humilation of or defeat),Anvīksikī,etc. have been used, but also there is a reference to the five member sentence or speech whose strong and weak points were thoroughly known to Nārada [2] In vanaparva,a chapter of Mahäbhärata there is a story about the controversy between vandi, the court philosopher of king Janaka, and Astā $v \bar{a} k r a$, a young scholar. The story is illustrative of the fact that the rules of controversy were known at the time of Mahäbhārata. It is certainly true that rules of controversy cannot be identified with the theory of logic. But it is the rules of controversy, which are primarily discussed in aphorisms of Aksapāda. So the reference to the rules of controversy in Mahābhārata is very important for the historical development of logic.

The Mahābhārata relates the story of a Brāhmaõa who on account of his being addicted to logic chopping all through his life was born a jackal in his next birth. [3] According to $V y \bar{a} s a$, spiritual doctrines cannot be communicated to those made callous by dialectics (tarkasāstradagdhāya). [4] Manu-samhita, though recommending $A n v \bar{\imath} k s \bar{l}$ (logic) as a useful and necessary study for a king and insisting on a hetuka and a tarkin being indispensable members of a legal assembly, [5] enjoins excommunication upon those dvijas(twice-born class) who have become skeptics (nāstika) owing to recourse to hetusāstra and set at defiance sruti and smruti, the two recognized sources of religion. [6] Manu urges that dharma is to be analyzed by means of argumentation in conformity with the Vedas. [7] Though there are several references to the necessity and usefulness of logic as well as debates and discussions, nowhere in Brāhmanic literature is logic appraised at its full value. On the contrary, its importance has been emphasized, if at all, to prove things in concurrence with the beliefs and doctrines of the Vedas whose authority was commonly acknowledged to be one of the several means of right cognition (ägama or sabdapramāna) in the Brāhmanical schools of philosophy. [8] As the Vedas present no set philosophy, the Upanisads likewise are diffuse and figurative in their expressions. It is for this reason that the Upanisads to which the germs of all later philosophical thoughts can be definitely traced have little to say about logical problems. [9] But the debates and the discussions found in the Upanisads may be regarded as the anticipations of the logical system that followed.

Upanisads, though they encourage debates and discussions, declare that truths regarding Brahman are not obtainable by argumentation alone (naisātarkenamatirāpaneyā). [10] It is also to be noted in this connection that an approach to religion or metaphysics purely from the standpoint of reason, quite irrespective of the conclusion that may follow, is not much favoured in Brāhmanicliterature in general. In Manusmruti there is a reference to tarkaor logic and it is asserted that those who follow tarka would not attain Svarga or heaven.

The most important fact about these all documents of logic is that they mention ten parts or Avayavās of syllogism instead of traditional five. Some of the Jain logicians like Bāhubali, also refer to these ten parts. These additional five parts of the syllogism are strictly irrelevant to the theory of syllogism and so Vātsyāyana, the commentator of Aksapāda Sutras rejects them. But certainly these additional five parts give rise to much speculation.

The story of Indian logic covers a period of over two thousand years. From the time of Mahābhärata, when logic was still a practical art of controversy, logical theory has steadily and constantly developed in India till about the seventeenth century A.D., when it culminated in a formal discipline of language in the neo-logical school of Navadeepa in Bengal. All this time it is spread through three different disciplines, the discipline of orthodox Hindu logic, the discipline of Buddhist logic and the discipline of Jain logic. Each of these schools produced many logicians of great eminence who attacked and counter-attacked the logicians of the other schools by trying to point out the weakness in the theory of the opponents. Thus, for example, Nāgarjuna,Dinnāga and Dharmakìrti tried to attack the Hindu logicians by pointing out the dimensions of Hetu(or reason)and its significance in the theory of inference. On the other hand the Hindu logicians tried to uproot the Apoha theory of negation, [11] which was accepted by Buddhist 


\section{International Journal of Science and Research (IJSR) \\ ISSN (Online): 2319-7064}

Index Copernicus Value (2015): 78.96 | Impact Factor (2015): 6.391

logicians. The result was that logical theory became richer and richer and culminated in the finest and subtlest instrument of human thought and reasoning. Philosophers of the other schools of orthodox Hindu thought also contributed to the growth of logic though they rejected the metaphysical tenets, they accepted the general methodology of NyāyaVaisesika school and soon thanks to their efforts it instead of remaining a mere school of philosophy, attained a position of pre-eminence in the science of methodology. Thus in ancient India a pupil was required to learn first grammar and then Nyāya or logic. Unless a student took lessons in Nyāya he was not supposed to be competent to study purvaMimāmsa or Vedānta.

\section{The Meaning of the Term Nyāya}

The earliest attempt to define Nyāya seems to have been made by vātsyāyana in his Bhāsyaon the Nyāyasutra. According to him it is the examination of objects by mean of pramānas. The definition seems to be wide, including as it does the ontological topics as presented in Nyāyasutra. Later on, particularly in the hands of the Buddhist logicians, Nyāya or logic became identified with the discussion of the pramānas. This seems to be the most general and current meaning of the term Nyāya in Indian philosophy. The carakasamhita contains for the first time an exposition of the doctrine of syllogism under the name of sthāpana. Hence it is presumed that the word Nyāya as an equivalent for logic came into use about the composition of that samhita that is, about the opening of the Christian era. The only systematic treatment of the Nyāya can be found in the Nyayyasatra of Gautama in later lines (Nyāyasåtra of Gautama- $2^{\text {nd }}$ century A.D./Uddyotakara-about 635 A.D./Vācaspati Mishra-about 841 A.D.).

The literature of Buddhism gives little aid; the Buddhist doctrine of perception in its developed form has affinity with the Nyāya, but no derivation suggests itself; either follows a line of thought already foreshadowed in the Upanisads. [13] The old pāli texts ignore the names Nyāya or vaisesika: in the Brahmajālasuttawe hear in lieu of them only of takki, 'Sophist' and vīmansī 'casuist' and in the Udānatakkikās appear as in the epic and Puranas.The silence is of importance, still more so the fact that in the Kathāvatthuppakarana,which does not claim to a greater antiquity than Asoka's alleged council about 255 B.C., we find no reference to either school, and nothing more significant than use of the terms patiñna, 'proposition', upanaya, 'application of a reason', and niggaha, 'humiliation', which later in Gautama's logic are technical terms, but which at this period have their more general sense. It is in keeping with this that the Nyāya, under the name $n \bar{t} t i$ and the vaisesika, first appear in the milindapañha.

\section{The Classical Nyāya School}

Founded by Gautama Aksapāda probably at second century A.D., the school, like its ally Vaisesika, represents the most stubborn proponent of realism in Indian philosophical tradition. Scholars have divergent opinions regarding the authorship of Nyāyasāstra. Some of them, for instance, Dr.Vidyabhusana, maintain that Gautama and Aksapāda were two different persons. Out of the five subjects discussed in the Nyāyasåtra, viz, (1) pramāna (2) prameya (3) vāda (4) avayava and (5) anyamataparīksa, the first, second and third, which constituted Anviksikī, were compiled by Gautama and the last two were introduced by Aksapāda. "Aaksapāda", according to Dr. Vidyābhusana, was, therefore, the real author of the Nyāyasutra, which derived a considerable part of its materials from the Anvīksikīvidya of Gautama. Just as Caraka was the redactor of the Agnivesatantra or the Ayurveda, Aksapāda was the redactor of the Anvīksikī of Gautama. Vātsyāyana, the author of the earliest extant commentary on the Nyāyas ${ }^{3}$ tra vaguely refers to some other commentators and gives different explanations of some terms or concepts, but their works are no longer available. It seems that there must have been a gap of at least two hundred years between Aksapāda and vātsyāyana.

Later Naiyayikās like Uddyotakara, Jayanta and vācaspati engaged themselves in explaining various theses put forth in Gautama'sNyāyasåtra, the fundamental text of the school, and vehemently defended them against, above all, their archrival, and the Buddhist non-realist.

Nyāya is mainly a logical and epistemological, and its metaphysics is mostly subordinate to or overshadowed by the Vaisesika metaphysical theory of category (padartha).So, as a common practice, we take the latter to bear the name "Nyāyavaisesika". The Nyāyavaisesika word is populated with real (sat), particular existents, including substances, quality-particulars, then, universals, particularities, the relation of inherence, and finally absence. The metaphysics is thing-oriented, with substance forming the central and the most essential category. Substances are the substrata of qualities, action and universals, etc. which inhere in them. They are either non-composite, like earthatoms, sky and selves, or composite, composed of indivisible, eternal atoms of the four elemental substances, earth, water, fire and air.

Nyāya accepts four types of means of knowing, viz. perception, inference, analogy and word-generated cognition. Unlike the Buddhist, the school draws a distinction between a mean of knowledge and the resulting knowledge. In any case a knowledge-episode (pramā) is and object-accordant (yathārtha) presentative cognition.

A cognition or awareness is a transitory quality of the self. Naiyāyikās denounce the thesis of self-awareness. For them an awareness-episode, unless it is pre-predicative, can be known by a reflective awareness called 'anuvyavasāya'. Now, according to Nyāya, a sense-awareness of an object is void of a concrete form, yet its reflection perceives not only the awareness itself but also the object. This problem is thus resolved: by dint of the first order awareness setting up, jñanalaksana-wise, an epistemic relation the reflective awareness comes to perceive even the object of the first order awareness.

For Nyāya there is no intentional content, e.g., concepts, that mediates between awareness and its external objectcomplex. The content of awareness is indeed its external object. For the Buddhist a conceptual awareness may ascertain as the same various different homogeneous objects. 


\section{International Journal of Science and Research (IJSR) \\ ISSN (Online): 2319-7064}

Index Copernicus Value (2015): 78.96 | Impact Factor (2015): 6.391

Projecting a conceptual-intentional form onto the objects does this. And different ascertaining awareness may have a very similar intentional form. But Jayanta (NyāyaMañjari 11: 26-27) repudiates the view as he argues that if the seemingly generic form revealed by the conceptual awareness is distinct from the awareness, then it is just a real phase of the latter, the form is as specific and instant $(k s a n i k a)$ as the awareness.

"The Nyāya system of philosophy is generally identified with logic. But it is by no means true that it is a system of logic alone and nothing else. It is primarily a method of controversy” [14] Logic, like Metaphysics, is only a part of it. It is a matter of history that adherents of the Nyāya system of philosophy laid great stress on methodology, which, in the course of time, was also accepted in large measure by other systems of philosophy to prove their propositions. Though it does prameya and apavarga amongst the categories, from the aphorisms, which have come down to us the metaphysical presuppositions of the system, are by no means clear. On the other hand it is clear that the system provides instruments of controversy and decision. But traditionally and in its later thought at least, the followers of the Nyāya system accepted the metaphysics of the Vaisesikās.In fact later Indian logic is mostly the development of vaisesika logic, unifying it with the main tenets of the Nyāya, In fact, even Udyotakara regards kanāda, the profounder of Vaisesika system as a great sage and adores him with even greater veneration than Gautama.

The author of the vaisesika system was kanāda. His other name seems to be Uluka. Etymologically 'kanāda' means one who eats atoms. Kanāda was, perhaps, so called because he believed that the world was composed of atoms. Like the Greek Democrats, he tried to reduce everything to four kinds of atoms, the atom of fire, the atom of earth, the atom of air and the atom of water.

The logics of the Vaisesikas and the Naiyayyikas proceeded for some time on parallel lines, but were ultimately unified in the neo-logical school. Perhaps the works of Udayana who wrote on both the systems must have been partly responsible for this unification. In fact some as the founder of neo-logical school has regarded Udayana. He wrote profusely and criticized almost every logical doctrine of the Buddhists. The systematization of the logical doctrines of Indian origin is most probably due to Udayana.

Udayana seems to have flourished in the $10^{\text {th }}$ century A.D. Most probably he belonged to the Saiva school of religious sect. One of his celebrated works, known as Kusumāñali-'A bunch of flowers'-is a work devoted to establishing the existence of God. In this work, as in others, he discusses in detail, the whole theory of logic and the work is indeed very important from the point of logical theory.

He wrote a commentary called Kiranāvali-'A beam of rays’on the Bhāsya of Praœastap̄āda and on Nyāya side wrote another commentary called Nyāya- vārtikatātparyaparisuddhi on Nyāya- vārtika- tātparya of vācaspati Mishra. Another important work of his is Atmavādaviveka where he tries to prove the existence of soul and analyses its nature. It is here that he discusses the Buddhist doctrines of Apoha and ksanabhanga or flux. He revived and re-established the Nyāya and Vaisesika theory. On account of his epochmaking work, the TatvaCintamaniGangesaUpadhyaya is usually called the father of neo-logical school. Udayana was, at least, responsible for preparing the ground for that great work of Gangesa.

Before Udayana, there flourished great logicians like Vātsyāyana, Udyotakara, Vācaspati Mishra, Bhāsañ̃àj Jayanta and several others on the Nyāya side. On the Vaisesika side there were celebrated authors like Prasastapāda, Sridhara and Vyomasiva. The work of Prasastapāda is known as Padartha-Dharma-samgraha. It is usually known as Bhāsya though an independent work running along the line of Vaisesika Sutra. It is very valuable because it is the earliest Vaisesikawork available. Unlike the NyāyaSutra which has been arranged by Vācaspati, Vaisesika Sutras are not properly arranged and the authenticity of many of them is doubted.

Another important work on the Vaisesika side is the Nyayakandali of Sridhara. It is a commentary on PrasastapādaBhāsya and shows a great advance in logical theory. Another very early commentary on the Bhāsya of prasatapāda is known as Vyomavati and is useful as it preserves many of the doctrines of Indian logic in its early form. When the new system of education was introduced in India, the study of Indian logic was neglected; the development of logic came to an end.

\section{The Buddhist School}

The Buddhist epistemological school is virtually founded by Dinnāga, a Yogācāra philosopher, at the early sixth century A.D. As Dinnāga and his successors also subscribed themselves to or made use of certain views of the Buddhist Sautrantika School, the school is also known as SautrantikaYogācāra school. Dharmakīrti later took up Dinnāga's theses, enlarged and refined them against criticisms from the rival schools. Dharmakīrti wrote a number of books explaining his viewpoints on perception, inference, language and relation, etc. Apart from Dinnāga and Dharmakīrti, we can refer to Sāntaraksita and his pupil Kamalasīla, especially, their new semantic theory. Although Yogācāra metaphysicians are idealists, the Buddhist epistemologists normally accept the existence of mind-independent reality. It is well known that in NyayabinduDharmakīrti says to the effect that a particular (svalaksana) gives rise to different immanent objective appearances according to it is near to or remote from the perceiver.

Buddhist literature generally falls into two divisions, Pāli and Sanskrit. In Pāli Buddhist literature there is not a single treatise devoted to logic; nevertheless it gives very clear indications of current logical doctrines. As Keith figures in the Pāli literature, Buddha is 'a reasoner whose interlocutors are not his match; his weapons against them, beside his authority are analogy, simile, parable and an occasional trace of inductions by simple enumerations of cases'. [15] We must also bear in mind in this connection that in the personality of Buddha the preacher and the philosopher blended together. While Buddha gave a rationalistic philosophy in an age of Upanisadic dogmatism, he had to 


\section{International Journal of Science and Research (IJSR) \\ ISSN (Online): 2319-7064}

Index Copernicus Value (2015): 78.96 | Impact Factor (2015): 6.391

deal with 'relatively immature minds', 'the man in the street' and 'the average bhikkhu or sekha (learner in the order). 'But any way the prevailing method of the Buddha in his replies to interlocutors is one of gentle 'reasonableness'. [16]

The period of Pāli Buddhism was rather one of criticism than of construction and it is not a matter of surprise that we do not find during this period any systematic study of logical principles. In the later period of Sanskrit Buddhism when the schism of the Buddhist institute resulted in the four principle schools of Mādhyamika, Yogācāra, Sautrantika and Vaibhāsika, every school for the purpose of opposing rival doctrines as well as vindicating its own, found it necessary to evolve logical methods of arguments and thus gradually there grew up a vast literature on logic which to our great misfortune, is now a mere catalogue of names. Excepting only a few, almost all the treatises on Buddhist logic are lost. But some have providentially escaped utter destruction as they were translated into Tibetan or Chinese. The Japanese scholar SadajiroSugiura has given an account of the Buddhist logic in Chinese and Japanese in his work, 'Hindu logic as preserved in China and Japan' (1900).Dr.Satis Chandra Vidyābhusana's monumental work-History of Indian Logic, (1921), presents an elaborate account of the Buddhist Nyāya literature which was transported to Tibet and remains up till now, buried in its Tibetan translation.

Dharmakīrti'sNyāyabindu with the Nyāyabindutīka is the only complete and comprehensive work on Buddhist logic that has survived in its original Sanskrit form. The six Buddhist Nyāya tracts (Bib. Indica) edited by MahāmahopādhyayaDr.H.P. æastri discusses some interesting problems of logic. The Tattvasamgraha of Sāntaraksita with Pañjikā of Kamala sīla (Gaekwad Oriental Series), an encyclopaedic Buddhist work, gives a comprehensive account of Buddhist logic. The Nyāyapravesa, Part I (Sanskrit text) and Part II (Tibetan text) in the above series in an important manual of the Dinnāga's school of logic. The pre-Dinnāga Buddhist texts on logic from Chinese Sources by Professor Tucci in the same series have no doubt been a very valuable publication. The publication of a few more works on Buddhist logic has, however, been announced in the Gaekwad Oriental Series. But that we possess of the Buddhist Nyāya literature is insignificant in comparison with what has perished of it.

It is much to be regretted that Buddhist logic has in recent times scarcely received any attention of the orthodox Indian

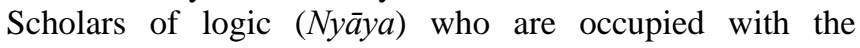
subtleties of the new school of Indian logic (Navya-Nyāya). But it is worth noting that Buddhist logic has had greater influence upon Navya-Nyāya than the ancient Brāhmanic logic. While Gautama introduces sixteen categories (padartha), rather topics of discussion in his logical system (i.e. the Nyāyasutra) the Buddhist logicians were restricted to one topic only, viz.pramāna. The Navya-Naiyayikas also exclusively confined themselves to pramā and discussion pertinent to it in their extensive and elaborate speculations in the field of logic. Gautama's Nyāyasutra has no reference to vyāpti or the invariable concomitance between the probandum and the probans, which is the pivot of inferential argument, though Vātsyāyana's suggestive remarks in his commentary on the Nyāyasutra 1.1.39 are worth noting. All the subtle discussions on the invariable concomitance or vyāptithat have found a prominent place in the NavyaNyāya have, it appears, been profoundly influenced by the theories of inference as held by Dinnāga and Dharmakīrti.

It is to be noted in this connection that the erudite Brāhmanic scholars like Uddyotakara, Vācaspati, Udayana and Partahasarati Mishra appear to have possessed a profound knowledge of Buddhist logic, which they exhibit in course of their criticism of the Buddhist doctrines.

The Jaina philosophers also took interest in Buddhist logic. Not only did they refer to the Buddhist views in their own works by way of criticism but they also sometimes wrote commentaries on the Buddhist logical treatises, e.g. Haribhadra'sNyāyapravesapañjikāon the Nyāyapravesa and Mallavādin'sDharmottaratippanaka (Bib.Buddhica) on the Nyāyabindutīka of Dharmottara. It deserves to be mentioned here that these commentaries along with the texts, Nyāyapravesa, Nyāyabindutīka(with Nyāyabindu) and a few more texts of Buddhist logic that have survived in their original Sanskrit form.

The Nyāyasutra of Aksapāda and the Bhāsya of Vātsyāyana show the influence of Buddhist critics like Nāgarjuna and refute some of their charges. Dinnāga then sets himself to criticizing Brāhmanic doctrines as those of Aksapāda and Vātsyāyana .To answer the objections of Dinnāga, urged against Aksapāda and Vātsyāyana,Uddyotakara made an attempt to interpret elaborately the Nyāyasutra of Aksapada and the Bhāsyaof Vātsyāyana with all their implications. And again as Buddhist criticisms on Aksapāda and Vātsyāyana led Uddyotakara to write his Nyāyavārtika, Brahmanic criticism on Dinnāga similarly induced Dharmakīrti to write the Pramānavārtika, a metrical commentary upon the Pramānasamuccaya effecting all possible improvements in their own defense. Dharmakīrti was again answered by Vācaspati, the great Brāhmaic Philosopher and commentator. Dharmakīrti was succeeded by a number of Buddhist logicians like Devendrabodhi, Vinītadeva, Jinendrabodhi, Santaraksita, Dharmottara, Arcata and jetari, many of whom wrote commentaries and sub-commentaries on the treatises of Dinnāga and Dharmakīrti and occasionally criticized Brāhmanic writers like Kumarila and Vācaspati. But they did not possess much originality of thinking like the two masters: Dinnāga and Dharmakīrti. Owing to these mutual conflict and opposition Indian logic had the opportunity of developing by a process of alternate criticism and construction.

"The continuity of Buddhist logic came up to about 1000 A.D. when the decline and fall of Buddhism in India sounded its death-knell. During this time with the revival of Brahmanism Brāhmanic logic being tinctured with Buddhist influence came to be studied over again and thus was laid the foundation of the new school of Brahmanic logic(NavyaNyāya) which flourished later on so luxuriantly in Mithila and Nadia". [17]

The history of logic in India presents three stages: The first stage, when dogmatic philosophy and authority reigned supreme and was thrown into the back-ground; the second stage, characterized by a rampant revolt against authority 


\section{International Journal of Science and Research (IJSR) \\ ISSN (Online): 2319-7064}

Index Copernicus Value (2015): 78.96 | Impact Factor (2015): 6.391

when logic was raised to the rank of philosophy and was on a par with it; and the third stage, when logic got the upper hand over philosophy and in a sense smothered it, but at last lost its self in its own groove. Buddhist logic, it is to be noted, belongs to the second stage.

Classical Indian epistemologists concerned themselves with examinations of various means of knowing (pramāna) regarding their number, functioning, object, validity, etc. The Buddhist accepts only two means of knowing, viz., perception and inference. It is often said that Dinnāga reduces verbal cognition to inference. In Pramānasamuccaya he does say that the cognition from the utterance of the worthy person is inferential, for it and inference similar in being non-deceiving. The two are also alike in being conceptual and having a negative route to reality. Yet, to affirm these similarities (and for under inference) is not necessarily to reduce verbal Cognition to inference. It may be the case that Dinnāga just found a common basis for both of them.

Dharmakīrti characterizes both perception and inference as a correct (samyak) knowing in the sense of being nondeceiving (avisamvādi) in its adherence to efficient operation or to the fulfillment of useful effect (arthakriya). It is held in Pramānavārtika11 6d-7a that the own form of a cognition is known through the practical activity of confirmation regarding the production of the intended effect. Dharmakīrti account of the notion of Pramāna in relation to its validity is pragmatic. Pramāna- vārtika- vrutti (Manorathanandin in pandeya-1989) however, suggests that when illusion, doubt and apprehension are absent, the validity of awareness is known intrinsically. [18]

The notion of non-deceiving does not define a correspondent relation with one relatum, the cognition, to represent the other, the intended object. As said, the notion means adherence to efficient operation. So, we need to see whether there is any discordance between what the cognition takes its object to be and the production of the concerned effect. One sees something as water from a fair distance but, when approaching it, finds no water there. Then, the first seeingexperience turns out to be deceiving; it disappoints or dissatisfies (visamvādin) the confirming experience.

On the other hand, the Buddhist views conceptual cognition as erroneous, for it apprehends the real through an unreal conceptual veil. [19] Thus, the immanent appearance of such cognition fails to conform to the form of the external object: it fails to present its object the way it is with its failure of conformance (arthasārupya) or its miss-presentation; a conceptual cognition can be both pragmatically nondeceiving and presentatively erroneous.

\section{The Epistemological Outlook in Early Buddhism}

Early Buddhism is primarily concerned with practical problems of life. Its aim is to attain supreme perfections through proper conduct. To attain this aim knowledge of truth and reality is necessary. Thus the problem of knowledge forms the basis for ethics and metaphysics in early Buddhism.
In AnguttaraNikāya, we find the division of knowledge into six kinds. [20] This is just a division of knowledge and has a little to do with the theory of knowledge.

The Buddha distinguishes between paranormal and sensory or intellectual knowledge and attack greater value to the former one by saying that it in "Profound, difficult to see and comprehend, serene, excellent super-rational, subtle and comprehensive only by the wise”. [21]

The highest knowledge [22] too, according to early Buddhists, is conceived by extra-ordinary visual perceptions, through the eye of wisdom. One is to know and see truth directly. It is interesting to see the significance of the use of 'knowing' and 'seeing' in Buddhism-The Buddha uses the word 'seeing' along with 'knowing' in many contexts. [23]

To both normal and paranormal perception Buddhism offers empirical explanations.

Inference (anumāna) in Indian thought necessarily both inductive and deductive process. While seeking for material truth corresponding to reality, mere formal truth would not serve. Probably this is the reason why tarka (Pali -takka), which is the method showing formal consistency, is not recognized by early Buddhist as an independent source of knowledge.

Early Buddhism bases its inference both a normal and Paranormal perception and we find many such references in Pāli texts. [24] This is the case of inference based on normal perception with regard to inference drawn on the basis of paranormal perception also there are many references. We find the Buddha asking monks to cultivate and practice the noble eight-fold path and saying 'whatever a monk cultivates the noble eight-fold path it leads him to Nibbāna'. [25] This kind of statements are said to be based on the direct paranormal perception of the Buddha himself. Many instances containing inferential passages are found in AnumānaSutta of Majjhima Nikāya. [26]

There are also references, to fallacies of inference based on both normal and paranormal perception in the canon.

The Buddha refuses to accept 'authority' (sabda) as valid mean of knowledge. Many scholars are of the opinion that the Buddha himself has adopted many views from preBuddhist thought. [27]

But the Buddha claims that he has influenced the old ideas on the basis of his own direct personal experience and not on the ground of authority. [28] His non-acceptance of authority as independent from his criticism of six ways of knowing based on authority. [29] He criticized that all six theories may be true or false. [30] The Buddha demands that his own statements should be tested and if found true can be accepted and if found false can be rejected. This shows that his attitude to authority is critical and not dogmatic. Saddhāfaith too, which is an important aspect in teaching of the Buddha, is not to be confused with uncritical, dogmatic and blind faith. 


\section{International Journal of Science and Research (IJSR) \\ ISSN (Online): 2319-7064}

Index Copernicus Value (2015): 78.96 | Impact Factor (2015): 6.391

\section{The Role of Tarka in Early Buddhism}

Many scholars have called the Buddha a rationalist in different senses. But many instances show him not to be in favour of rational theories, rather we see him criticizing rationalists (takki) in pāli cannon. Moreover he has dissociated himself from the class of rationalist (takki) and traditionalists (anussāvika) and has associated himself with experiencialists. We find him criticizing the four different kinds of knowledge based on reason viz. 1.takkahetu, 2.Nayahetu, 3. Akkāra-parivitakkana and 4.ditthinijjhānakkhanti. In all these forms of reasoning their unreliability is pointed out on the ground that they may be well or ill reasoned and true or false.

Though reason has not been accepted as a means of valid knowledge, its limited value is not ignored. [31] It is utilized to expose the absurdity of the opponents view by pointing out its inner-inconsistency and indirectly to show the validity of one's position. [32]

Buddha lays emphasis upon individual experience and not infrequently he declares in express terms that the path to be adopted is what one oneself recognizes as true. "Then monks, what you have just said is only what you yourselves have recognized, what you yourselves have comprehended, what you yourselves understood, is it not so?" "It is even so? Lord”. [33] The Lord Buddha is said to have admonished his followers on one occasion thus: "Do not accept, oh Bhikkus, my words out of any respect for me, but accept them for what they are worth after proper scrutiny, just as a piece of gold is accepted by an expert after it is put to fire, cut or tested on the touchstone". [34] "No sentence”, to quote Mrs. Rhys David, "occurs oftener than Tam kissahetu? What is the reason of that?" [35] In PāliTripitaka. This tendency of Buddhism to appeal to reason and argument accelerated the development of logic in the hands of the Buddhist philosophers who took it up with all earnestness for the purpose of challenging the antagonistic views and vindicating their own.

\section{The Use of 'Upamā' in Canon}

Comparison (Upamā), though not accepted as a valid means of Knowledge, has not been ignored as useless. In many instances parables and similes have been used to make the views clear to the nearest. A section in MajjhimaNikāya is called OpammaVagga [36] as it is rich in parables and similes. The Buddha was well aware of the intellectual gradation amongst his disciples in the discourse to give clear meaning of the idea contained in them.

\section{The Art of Debate in Kathāvatthu}

About hundred years after the passing away of the Buddha the monks had differences of opinions regarding the actual sayings and the interpretations of their master. The dissensions brought, about schism in the Sangha and within two or three centuries after the Buddha's death as many as eighteen sects arose. Each of these sects in order to hold their views firmly started criticizing the views of others. The resorted to arguments in the form of debate to condemn their opponents. This is evident from Kathāvatthu which was compiled during the reign of Asoka in the Third Buddhist council.

In Kathāvatthu the heretical doctrines were thoroughly examined and refuted. Its attempt is to reduce the view of the heterodox schools to absurdity. The discussion proceeded in the form of question and answer and the answer of the opponent are often shown to be based on the contradictory assumptions.

The text opens with the controversial point whether the Soul (Pudgala) is known in the sense of a real and ultimate fact or not. Theravādins do not admit the existence of soul (Pudgala) as an ultimate fact while Pudgalavādins, the respondents, assert that there is an ultimate reality called Soul (Pudgala).

\section{They argue:}

Theravādins- Is the Soul (Pudgala) known in the sense of a real ultimate fact (is $\mathrm{A}=\mathrm{B})$ ?

Pudgalavādins -Yes.

Theravādins-Is the Soul (Pudgala) known in the same way as a real and ultimate fact is known (is C=D)?

Pudgalavādins- No that cannot be said.

Theravādins- Acknowledge your defeat.

If $A$ is $B$ then $C$ should be $D$. But as $C$ is not $D$ therefore $A$ should also be not B. Here B is affirmed of A but not D of $\mathrm{C}$, which is false and so the answer is refuted. This is the cause of anuloma and in contrast to this indirect method (patikamma) is used by the Pudgalavādin to prove Theravādin wrong where in the Theravādin affirms not B of A but deny not $\mathrm{D}$ of $\mathrm{C}$ which is wrong according to Puggalavādins.

When the arguments take place between the two they use Niggaha (the rejoinder causing defeat of the opponent).Upanaya (application) Nigamana (conclusion) etc. to strengthen their arguments. In course of their arguments they change the place that is to say sometimes the Theravādin is a respondent and sometimes the Puggalavādin. The subject matter of the argument also changes with reference to space, time and things. When a case is presented through a simple comparison, it is called Suddhikasamsandana.For example:

Pudgalavādin maintains that $\mathrm{A}$ is $\mathrm{B}$ and $\mathrm{M}$ is $\mathrm{B}$ and also say that $\mathrm{A}$ and $\mathrm{M}$ are not distinct. To this the Theravādin answers if we assert separately that $\mathrm{A}$ is $\mathrm{B}$ and $\mathrm{M}$ is $\mathrm{B}$, Then $\mathrm{A}$ and $\mathrm{M}$ should be distinct.

A section on Lakkhanayuttikatha deals with the definition of terms, while another section on 'Vacanasodhana'deals with distribution of terms. In the controversy of vacanasodhana the extension of the subject in relation to its predicate is set forth. Theravādin ask whether all A is B and all B is A. To this Puggalavādin answers all A is B But some $\mathrm{B}$ areA and some are not. This shows how the early Buddhists were conversant with the distribution of terms.

Thus we see that the doctrines are put forward in the form of Questions and answers and systematic logical methods are applied in this debate of Kathāvatthu. Though not a separate logical treatises of the later time, many technical terms of 


\section{International Journal of Science and Research (IJSR) \\ ISSN (Online): 2319-7064}

Index Copernicus Value (2015): 78.96 | Impact Factor (2015): 6.391

logic found in Nyāya treatise already find mention in kathāvatthu. B.C. Law has rightly observed that "In kathāvatthu, we have a great book of controversy which lies at the immediate background of the entire Nyāya literature". [37]

\section{The Use of Dilemma in MilindaPañha}

Milinda Pañha [38], a beautiful prose wrote has its unique position in the non- canonical Pāli literature. Apart from being a comprehensive exposition of Buddhist metaphysics, ethics and psychology, Milindapañha is the only $\mathbb{a} \mathbf{P}$ work which an explicit reference to logic called nīti or $N y \bar{a} y a$. It contains questions of king Milinda who was well versed in logic and the answers of Nāgasena, who seems to surpass the former in the same, or various topics. The dialogue between them shows how scholars carried on debates and arguments in these days.

Fourth book of the text viz. 'MendakaPañha' contains many dilemma put forward by the king for the venerable one to solve. For instance-Milinda asks Nāgasena to explain why the Buddha refused to answer certain questions. He added he must have refrained from answering out of ignorance or out of wish to conceal something (A is either B or not B). Either of the disjunctive statements should be true. To this double pointed dilemma Nāgasena answered in negative saying that neither of the statement is true (A is neither B nor not B) and explained that the questions put to the Lord were not to be answered as there is no reason or object for answering them, the very nature of those questions was such that they could not but be put aside.

\section{The Nature of Questions in Buddhism}

Truth or falsity can be asserted of a proposition only after it has been tally analyzed. Buddha who claims to be an analysts, [39] distiguishes between categorical and noncategorical propositions, while saying, "I have taught and laid down doctrines which cannot be categorically asserted.” [40] The four noble truths come under the first group and the 'Avyākatavatthuni'under the second. Some of the noncategorical propositions are analyzable while some others are non-analyzable. Thus division of statements according to their truth-value resulted in a division of four types of questions. There are the four types of questions ('cattārimāni......pañhavyakaraõāni'):

1) EkamsaVyākarasa - question which are explained categorically.

2) PatipucchaVyākaranīyo - questions which are answered after a counter-question has been put.

3) VibhajjaVyākaranīyo - questions which are explained analytically and

4) Thapanīyo - questions that are set aside. [41]

However in the Pāli canon, apart from this classification of questions we hardly find any explanation or illustration, which was later provided in the Abhidharmakoùa. [42] Of these four types of questions the Thapaniya or the Avyakata - the inexpressible ones find mention in many dialogues of the canon. Then metaphysical theses are enumerated. [43]
The Mahāsanghikas extended this to fourteen theses by adding four, logical alternatives to 'sassatoloko'and 'antavāloko' on which the Buddha refused to give any answer and set them aside. The Buddha thought that none of the logical alternations could be categorically asserted. So he preferred keeping silent. This 'silence' of the Buddha later formed the basis of Mādhyamikas dialectic.

The history of Buddhist thought evinces two types of following of the Buddha, one philosophical and the other theological. Theologically, his followers from two camps known as Hīnayāna and Mahāyāna, each having many sects and sub sects were spread in the world. Philosophically, Buddhist thought in India has four broad divisions, namely,Vaibhāsika, Sautrantika, Madhyamika, and Yogācāra.NārāyanaBha $\mu \mu$ in Mānameyodaya cryptically summarizes the basic thrust of each of these four schools as follows:

"MukhyoMādhyamikovivartamakhilamsunyasyamenejagat Yogācāra mate tusantimatayahtesāmvivarto'khilam artho'stiksanikotvasavanumitokathyetiSautrantiko pratyaksamksanabhanguramcasakalamVaibhasikobhāsate”.

That is, the Mādhyamika is the most important philosophical school, which regards the entire world to be an apparent manifestation of sunya. The next school is Yogācāra, according to which ideas alone are real, and the entire world is an apparent manifestation of ideas. The third school is that of the Sautrantikas, which maintains that there are objects existing independently of the ideas, but they are momentary, and their existence is known only through inference. The last school is known as Vaibhāsika, which holds that all objects are momentary and perceivable.

For the sake of easy understanding, these four schools can be put in a particular logical order as Vaibhāsika, Sautrantika, Mādhyamika, and Yogācāra. Perhaps this may also be the chronological order. All these four schools claim authenticity and faithfulness to Buddha's thought. Buddha was quite prolific in his ideas, and it may not be difficult to find rudiments of all these four schools in his thoughts. The doctrine of impermanence (anityata), which subsequently was formulated as the doctrine if momentariness (ksanikavāda), and the doctrine of dependent origination (pratityasamutpada) are the common planks for all these four schools. All the schools believe in the ideas of rebirth and nirvanna. Their deference is only in terms of the development of logical structures based on these doctrines and ideas. I shall briefly discuss the major points of difference characterizing each of these schools. The school of Mādhayamika and Yogācāra (Vijñānavāda) are idealistic in their thrust and are associated with the Mahāyāna tradition. However, these four schools constitute significant facets of later Buddhist thought.

\section{Vaibhāsika School}

The Vaibhāsika School seems to have acquired this name because it relies upon a commentary on the Tripitakaknown as Vibhāsa . This school upholds dualism of mental and physical elements. All that is real is momentary, and either physical (bhuta) or mental (citta). The object of the world are a conglomeration of either physical elements or mental elements or both. No object is permanent or abiding, but 


\section{International Journal of Science and Research (IJSR) \\ ISSN (Online): 2319-7064}

Index Copernicus Value (2015): 78.96 | Impact Factor (2015): 6.391

since it is in the form of an incessant series, it gives the impression of permanence. These objects are directly known in perceptual cognition. When there is simultaneity of appearance of the cognizing consciousness. Likewise, a cognizing consciousness may also exist independently of the cognized object. In this way, the Vaibhāsika School advocates dualism in its metaphysics and realism in its epistemology. The Vaibhāsika School concentrates more on the analysis of mental phenomena, and we find an elaborate psychological analysis in the literature belonging to this school.

\section{Sautrantika School}

The Sautrantika School derives its name from a commentary called Sutranta. It is also a realistic school, sharing its metaphysics with Vaibhāsikas. Sautrantikas believe in the momentary existence of the real and classify them into mental and physical. The mental and the physical are basically independent of each other, though subsequently they may interact. Sautrantikas regard the object to exist independently of the noetic process. The object, the cognizer, and the cognition are all distinct. The object may be known or may not be known. If an object is known, it cannot be known in direct perception. In this respect they differ from Vaibhāsikas. According to Sautrantikas, the moment of existence of the object and the moment of the cognition of the object cannot be the same because cognition follows and presupposes existence, and every existence precedes its cognition. There cannot be simultaneity of existence and its cognition. The sautrantika thinkers examine and refute the Vaibhāsika position in this respect. In fact, this is the major point of difference between the two schools. The Sautrantikas argue that the object of knowledge exists independently of the cognizing consciousness, and it ceases to exist in the next moment. So, when it comes into existence at the very moment, it is not cognized, and it cannot be cognized. It does not exist in the next moment to be perceptually cognized, so there is never any perceptual cognition of an object. However, it does not mean that an object can never be cognized. There is another mode of cognizing an object. Before an object ceases to exist, it leaves out its impression this impression is the exact copy of its original and has semblance (sārupya) with it. The cognizing consciousness perceptually apprehends only this impression, and through this perceptual apprehension of the impression it infers the original object. Thus, Sautrantikas introduce the concept of object impression and through this advocate the representative theory of perception. For them all cognitions are represented cognition of the object. An object-Qua-object is not directly perceived. Only its impression is perceived, and because of the resemblance of the two and cognitive non-availability of the object the impression is taken to be the original object.

\section{Mādhyamika School}

The third school is Mādhyamika, which is philosophically very significant. Nāgarjuna has been the first known exponent of this school. He argues that Buddha's teaching consisting in the madhyamapratipada(middle path) to be followed for the realization of nirvāna, which is cessation of all suffering. According to Nāgarjuna, Buddha advocated sunyatā(essencelessness) of all existence. All existence is sunya(essenceless) in the sense that they do not have self- existence (svabhāva).Every existence has a borrowed existence or a dependent existence (pratītyasamutpanna); svabhavasunyata (lack of independent existence) characterizes all reals. The same position holds good in respect of all thought and language. Just as all real is selfnegating, all thought and all language are also self- negating, Nāgarjuna exposes the hollowness and self-contradictory nature of the important concepts and doctrines prevalent in his time in Buddhist and non-Buddhist philosophies. He successfully employs the weapons of sunyata and pratītyasamutpada to demolish all systems of metaphysics.

He advocates a twofold approach to reality in terms of samvrutisatya(empirical real) and paramārtasatya(transcendental real).Both are characterized by sånyata in different ways. Empirical is Svabhāvasunya (devoid of intrinsic existence), and transcendental is prapañcasunya.Byprapañca he means display of thought and language. Nāgarjuna emphasizes the anti-metaphysical, practical, and pragmatic nature of Buddha's teaching and lays stress on the attainment of prajña(wisdom) leading to sìla(noble conduct)and samādhi(state of equipoise).This school is known as Mādhyamika because of its emphasis on madhyamapratipada, which is a practical middle path, avoiding all extremes. It is known as Sunyavāda because of its exposition of essencelessness of all real on account of its dependent character.

\section{Yogācāra School}

The pluralistic and realistic philosophy of the Sarvāstivāda culminates in a monistic and idealistic philosophy of Vijñānavāda (Yogācāra) by way of critique and rejection of Sunyavāda. The representative theory of perception of the Sautrantikas implies that all that is cognized is the content of cognition, and the content of the cognition has a form of its own, which has sameness of form (sārupya) with the form of the object. It resulted in the theory of $s \bar{a} k \bar{a} r a j n \bar{n} n a v \bar{a} d a$, a theory according to which every-cognition has a form of its own apart from the form given to it by its object. From the theory of sākārajñānavādathere was a natural transition to the theory that only contents of cognition or vijñannas(ideas) are real and that they alone are cognized. The external objects are only hypostatization. They are presumed to be there, but, in fact, they are only projections of the consciousness. Consciousness alone is real. Thus, in Vijñānavāda we find repudiation of the theory that the object of cognition exists externally and independently of the cognizing consciousness (bāhyarthavāda). The consciousness that alone is primarily real is momentary and is in the form of a continuous flow (pravāha). The Vijñānavāda advocates three levels of reality, namely, parikalpita(imaginary), pāratāntrika(dependent or empirical reality), and pāramārthika (transcendental reality). Transcendental reality is conceived to be unitary stream of consciousness, technically known as älayaVijñanna. It is a storehouse of consciousness in the sense that it is the foundation of all streams of consciousness that are responsible for the appearance of the world of external objects. It is a repository of the old impressions (samskāras) and a depository of new impressions. In this way alayavijñana is the only ultimate reality. In itself it is pure and cannot be characterized. It can be experienced only in the state of nirvāna. The other level of reality is empirical, 


\section{International Journal of Science and Research (IJSR) \\ ISSN (Online): 2319-7064}

Index Copernicus Value (2015): 78.96 | Impact Factor (2015): 6.391

which consists of finite stream of consciousness and objects of consciousness. It is the level of the empirical world that we experience in our ordinary life. It is a reality that is amenable to empirical knowledge and linguistic expression. It is empirical reality (samvrutisatya), as different from transcendental reality (pāramārthikasatya).

According to those Buddhist sectors Buddhist logic split into two main schools such as Hīnayāna (Theravada) and Mahāyāna. Due to the differences of their opinions, the nyāya of one school is not applicable to the other. In particular, the Nyāya analyses of such Mahāyānic teachers as Dinnāga and Dharmakīrti are not relevant to the Theravāda. Ven.HagodaKhemanandaThera (A Sri Lankan Buddhist Scholar) has scrutinized the Theravāda Buddhist Logic in his Great work named "Logic and Epistemology in Theravāda" [44] Ven.Thero has explained like this: "The practice of certain scholars to mix all such divergent Buddhist Nyāya systems is baffling to the average Buddhist who seeks clear understanding of the matter. Although some such fundamental principles as the Four Noble Truths are common to all schools, there is a marked difference in the analysis of the sources of knowledge between Mahāyāna and Theravāda. Therefore, it is not appropriate to take what may be called Buddhist Nyāya as one homogeneous system. What we would like to stress is that a Nyāya for Theravāda has to be built solely on the basis of the Pāli Tripitaka”. [45]

There are a sizeable number of Nyāya treatises compiled by both Mahayana teachers like Nāgarjuna and Hīnayāna teachers belonging to such schools as Sarvāstivāda. Some call all such schools, with the exception of Theravāda, 'Northern Buddhism' for the reason that they subsequently existed in Northern India. Equally, the pāli Buddhism which found a home in Sri Lanka and Southern India is called 'Southern Buddhism'. Therefore it seems reasonable to call all forms of Buddhist Nyāya compiled in Sanskrit, whether they are Hīnayāna or Mahāyāna, 'Northern Buddhist Nyāya' and the Nyāya in Pāli which belongs to Southern Buddhism 'Theravada Nyāya' or 'Southern Buddhist Nyāya'. The Northern Buddhist Nyāya is rich in content. It is believed that Dinnāga alone compiled more than one hundred Nyāya treatises.

The Tripitaka which consist of Sutta, Vinaya and Abhidhamma is the content of Theravada. It has existed in Sri Lanka for twenty two centuries and Myanmar, Thailand and Campuchia for fifteen centuries. The learned Mahātheras (High priests) of these countries have enriched the Buddhist literature by compiling commentaries, subcommentaries and various other exegetical works. Nevertheless, in this literature as it is at present, we do not find any work on Logic or Nyāya. Although some tend to describe Nettippakarana as a TheravādaNyāya work, in actuality what it contains is only some method of explaining the doctrine. In other words, this work tells us how a given statement from the teaching (of the Buddha) may be explained meaningfully. Petakopadesaclosely follows the former. In addition, there are Saddasāratthajālini, Saddattabedhacintāa, Ditthantaratanāvali and Nītipadavali which have been subsequently added to the same line of thought, but none countable as a Theravada Nyāya work.
There are reasons to believe that the Theravada tradition had some Nyāya works in the past. The Sri Lankan commentator Mahānāmathera who wrote during the reign of king Kumaradāsa,516 A.D., supports his explanation to "suñ̃̃oloko" in Patisambhidāmagga by referring to a Nyāya work that presumably existed in his time. [46] A similar reference to a Nyāya work is available in Dāthavamsa of the $13^{\text {th }}$ century. [47] In addition, it must be mentioned that there are some Nyāya methods scattered in many parts of the Tripitaka.

The reasons not to develop the Theravāda Buddhist Nyāya are mentioned By Ven.Khemananda thero as follows:

1) People in those countries were less dogmatic and more pliable compared to the Brahmins in India. And this may have contributed to the situation that the Buddhist teachers did not require logical treatises to convince the local groups.

2) An ancient tradition of early Buddhism (represented in Atthaka and Pārāyanavaggās of Suttanipāta) underscore the view that debate is a result of dogmatism, and that such exercises would not conduce for emancipation. This explains why the Theravādins were less enthusiastic about developing an art of debate.

3) Theravādins were very particular about the pristine purity of their doctrine, and they made sure that it was not corrupted by any heretic views. Whenever there was an attempt to introduce any doctrine, which was against Theravāda, such an attempt was thwarted at the very outset. This may have done away with the necessity in the Theravada tradition of forming any logical treatises.

4) Finally, the Theravādins did not require separate treatises of logic for the entire Tripitaka was arranged in such a way that it facilitated the logical understanding of truth. In particular, the AbhidhammaPitaka reveals the Theravāda philosophy, and the study of the Visuddhimagga will give the student the quintessence of Buddhist logic. [48]

\section{Conclusion}

The Indian logic covers a period of over two thousand years. From the time of Mahābhārata, till about the seventeenth century A.D., when it culminated in a formal discipline of language in the neo-logical school of Navadeepa in Bengal, it is spread through three different disciplines, the discipline of orthodox Hindu logic, the discipline of Buddhist logic and the discipline of Jain logic.The earliest reference to logic or science of debate seem to be contained in chāndogyaupanisadand the Mahābhārata is very important for the historical development of logic.in Brāhmanic literature. Dinnāga and Dharmakīrti, Sāntaraksita and Kamalasīla are eminent Buddhist logicians who have compiled Buddhist logical rules in order.

Udyotakara,Vātsyāyana, Vācaspati, Udayana and other Hindu logician have made a theoretical preparations for Indian logic.

\section{References}

[1] Kathavatthu.Siameseedit.quoted by S.C.Vidyābhusaõa F.234.

Volume 6 Issue 1, January 2017 


\section{International Journal of Science and Research (IJSR) \\ ISSN (Online): 2319-7064}

Index Copernicus Value (2015): 78.96 | Impact Factor (2015): 6.391

[2] Mahābhāratasabhāparva, 5 adhyāya,5.

[3] MahābhārataSāntiparva,adhyāya 180.47-49.

[4] “natarkasāstradagdhāyatathaivapisunāyaca”. ibid.,adhyāya 246, 8.

[5] "traividyohetukastarkīnairuktodharapātakah trayascasraminopurveparisadsyaddasāvarā” .Manusamhitā,Adhyāya 12,111.

[6] “ yo'vamanyetate mule hetusāstrāsrayāddvijah sasādhubhirbahiskāryonāstikovedanindakah" .Manusamhitā,adhyāya 2,11.

[7] "ārùamdharmopadesamcavedasāsterāvirodhina yastarkenānusamdhattesadharmamvedanetarāp" Manusamhitā,adhyāya, 12,106.

[8] See Vidyābhsana's History of Indian Logic pp.36-39.

[9] For the roots of the Nyaya-vaisesika doctrines in the Upanisads,SeeRanade's “A constructive survey of the Upanisadic philosophy”,p.190.also compare prof. S.Radhakrisna`s remarks about Nyāya logic in his Indian philosophy,vol.1(1923).p.263.

[10] Kathopanisad, 1.2.9.

[11] Which states, that an entity is the negation of its opposite.

[12] Rhys Davids,Buddhist Psychology.,p.68.

[13] Vide. Barlingay S.S., A modern introduction to Indian Logic.,p.1.Introduction

[14] Keith A.B.-Buddhist Philosophy. 303.

[15] Rhys Davids C.A.F.-Logic (Buddhist) in Hasitings' Encyclopedia of Religion and Ethics.p.132.

[16] Chatterji D.C., Buddhist Logic-Article, Annals of the Bhandarkar Oriental Institute.Vol.34.

[17] Pramāna-Vārtika-Vrutti, 4. Likewise, in his TarkabhāsaMoksākaragupta holds that in hearing sound or seeing far away objects like the moon, the validity of awareness consists in the very experience of the ownform of the objects irrespective of the actual attainment of efficient operation pertaining to the object.

[18] In PramānaViniscayaDharmakīrti defines error (bhrānti)as consisting in grasping that (a real object)in non-that (an intentional);see katsura-1984.233,n.64.

[19] Cakkhuviññānam _ (ocular consciousness)

Sota ", - - (auditory consciousness)

Ghana ,, - - (olfactory consciousness)

Jivhā , - - (gustatory consciousness)

Kāya , - - (tactual consciousness) and

Mano „, - - (mental consciousness).

[20]“

Gambhīrāduddasāduranubodhāsantāpanitāatakkavacar ānipunāpanditavedaniyā"-DighaNikāya. 1. 12.

[21] Pāli canon refer to six fold higher knowledge attainable after the fourth stage of Jhāna (meditation) viz.1.iddhividha multiple forms),2.dibbasotadhātu(clairaudience),3.cetopariyajñan a(telepathic knowledge),4.pubbe niwasanussatijñāna(retro cognitive knowledge),5.dibba cakkhu(clairvoyance) and 6.āsawakkhayajñāna(knowledge of the destruction of defiling elements).

[22] “tamahamjānāmipassāmi

"Majjhima Nikāya,1.329/"jānatā,passatā’’M.N.11,111./Nibbāna is also said to be seen "nibbānampasseyyamti”,M.N. 1.511.

[23] SuttaNipāta furnishes with an inferential method to show how there can be no caste-distinctions. The trees, worms, ants, serpents, birds and other creatures possess characteristics denoting species ("lingam jātimayam")). So we find different species among them (“aññamaññajātiyo"). But among human beings there is no such characteristics denoting species (“evamnatthimanussesu lingam Jātimayamputhå”).So it is concluded that there can be no species or caste among them(“manussesvetamnavijjati”)SuttaNipata 117-119.

[24] “evam....bhikkhuariyamatthangikammaggambhavento ....nibbānaninnohoti”.Samyukta Nikāya.,v.58

[25] "tatrāvusobhikkhunāattanāvāattānamevamanuminitabb am"-the last word of this line suggests to give the sutta the title Anumāna to mean 'inferring'. One of the many references contained in this sutta is - 'the man of evil inclination is displeasing and disagreeable to me, and of I incline to evil, others will regard me likewise as displeasing and disagreeable. Realizing this almsman must train his heart never to give way to evil inclination'. AnumānaSutta- MajjhimaNikāya.

[26] The inference here is like - 'if P then Q, not Q therefore no Q'.

[27] 'Principles of Gautama’ says Prof. Rhys David, can be 'found in one or other of the orthodox systems'.Buddhism., pp 83-84., 'Early Buddhism is not an absolutely original doctrine’-Dr. S. RadhakrisnanIndian Philosophy., vol.1.

[28] “nāñ̃̃assasamanassavāBrahmanassavāsutvavadāmi,api cayad mayāsomamñātamsāmamditthamsāmamviditam tat eva'hamvadāmiti"-SamyuktaNikāya.,v 390.

[29]1.Anussava-traditional hearings

Vedas), 2 Paramparā-tradition in general,3.Itik Vepor,2.Parampara-tradition in general,3.tikiräyasampadā-scripture in general,5.Bhavyaråpata-eminence of the speaker and 6.Samano no garu-prestige of the speaker.

[30]Sussutamtathā-well remembered and true, Sussutamañnatā-well remembered and false, Dussutamtathā-ill rememebered and true, Dussutamaññathā-ill remembered and false-Majjima Nikāya-1.520.

[31] In Apannakasutta we find the Buddha asking people to decide their course of life on purely rational grounds, if they are not in a position to see the objective truth. Reason thus can act as pointer to the right path.

[32] If water purification can free one of evil karma (A) then the Fishes, tortoises, frogs etc. will go straight to heaven,(B)But B is absurd and false so it implies the absurdity of A.-Therigāthā.,240-1

[33] MajjhimaNikāya,XXVШ.The rationalistic aspect of Buddha's doctrine finds a brilliant exposition in George Grimm's “The doctrine of the Buddha or the religion of Reason”, Leipzing-1926.

[34] "tāpācchedāccanikasātsuvarnamivapanditaih parãksyabhiksavograhyammadvaconatu gaūarav ”.Tattvasamgraha,Kārikā,3588.

[35]Rhys Davids C.A.F., Logic (Buddhist);Hesting'sEncyclopaedia of Religion and Ethics;Vol.8,132.

[36] Opammavagga contains sections on parableskakacupamā (discourse on parable of saw) alagaddupamā (discourses on parable of water snake) hatthipadopamā (simile of elephant foot print) and Saropamā (simile of pith). 


\section{International Journal of Science and Research (IJSR) \\ ISSN (Online): 2319-7064}

Index Copernicus Value (2015): 78.96 | Impact Factor (2015): 6.391

[37] Law B.C-History of Pāli literature-p.646.

[38] MilindaPañha was probably composed in 100 A.D. There are many controversies regarding its exact date.

[39] 'vibhajjavādo...aham' -MajjhimaNikāya 1.197.

[40] “ekamsikapi......mayādhammādesitapaññattä’-Dīgha Nikāya.1.191.

[41] "ekamsavacanamekamvibhajjavacanamparamtatiyampa tipuccheyyacatutthamthāpaye"-Anguttara Nikāya.1.197.

[42] "ekamsenavibhāgenaprechatahsthāpanīyatahvyakrutam maranotpattivisistātmānyatādivat"-AbhidharmaKosa. v.22.

[43] Sassatoloko-The world is eternal,Assassatoloko-The world is not eternal,Antavaloko-The world is finite, Anantavaloko-The world is infinite, Tam jīvam tam sariram-The Soul is identical with the body,Aññamjīvamaññamsarīram-The soul is different the body,Hotitathāgatoparammarana-The tathāgata exists after death,Nahotitathāgatoparammaranā-The tathāgata does not exist after death,Hoticanahoticatathāgatoparammaranā-The tathāgata exists and does not exist after death,Nevahotinahotitathāgatoparammaranā-The tathāgata neither exist nor does not exist after death.

[44] Khemananda H.Ven.;Logic and Epistemology in Theravāda(TheravādaNyāya), Translated from Sinhala by:AsangaTilakaratne,Karunaratna and Sons Ltd,1993.(Available in Buddhist Cultural Center, Dehiwala-Sri Lanka.

[45] Ibid, p.2

[46] "Tathanāyaganthecasaddaganthecaayamevaattho".

(pauisambhida auphakatha,Hevavitarana Edition.p.358.)

[47] "Santappayamdhammasudharasena-

Yomānusetundilasukaropi

Isīvakatvāathanāyaganthamnijampavattesicirāyadham mam” ( Dāthavamsa,41.)

[48] KhemanandaH.Ven.; Logic and Epistemology in Theravada,pp.4-5. 